\title{
Karakteristik dan Bentuk Orkestra Nusa Octave SMA NU 1 Gresik
}

\author{
Rr. Rahmadiana Ramadhanty \\ Program Studi Seni Musik, Fakultas Bahasa Dan Seni, Universitas Negeri Surabaya \\ Email: dianaramadhan5@gmail.com
}

\begin{abstract}
Nusa Octave is an orchestra from SMA NU 1 Gresik which developed until now. Moreover, Nusa Octave became the only orchestra music in Gresik. This research to describe the characterisctics and forms of the orchestra Nusa Octave SMA NU 1 Gresik. Problem formulation in this research is: 1) How forms of the orchestra Nusa Octave SMA NU 1 Gresik, 2) How characteristics of the orchestra Nusa Octave SMA NU 1 Gresik. This type of research is descriptive qualitative research. The results of research and discussion show that Nusa Octave is an unique orchestra, not all schools have it facilitated by a variety of tools and large music room. There are many primary and secondary characteristics of the orchestra, can be made a good example to be known to the public. Therefore, really needs appreciated, preserved, and maintained.
\end{abstract}

Keywords: Characteristics, Forms of the Orchestra, Nusa Octave.

\begin{abstract}
Abstrak: Nusa Octave merupakan orkestra dari SMA NU 1 Gresik yang berkembang hingga saat ini. Selain itu, Nusa Octave menjadi satu-satunya musik orkestra di Gresik. Penelitian ini bertujuan untuk mendeskripsikan karakteristik dan bentuk dari orkestra Nusa Octave SMA NU 1 Gresik. Rumusan masalah dalam penelitian ini adalah: 1) Bagaimana bentuk orkestra Nusa Octave SMA NU 1 Gresik, 2) Bagaimana karakteristik orkestra Nusa Octave SMA NU 1 Gresik. Jenis Penelitian ini merupakan penelitian deskriptif kualitatif. Hasil penelitian dan pembahasan menunjukkan bahwa Nusa Octave merupakan orkestra yang unik, tidak semua sekolah memilikinya dengan difasilitasi alat yang bervariatif dan ruangan musik yang luas. Terdapat banyak karakteristik primer dan sekunder orkestra, bisa dibuat contoh yang baik untuk dikenal masyarakat. Untuk itu, sangat perlu diapresiasi, dilestarikan, dan dipertahankan.
\end{abstract}

Kata Kunci: Karakteristik, Bentuk Orkestra, Nusa Octave.

\section{PENDAHULUAN}

Zaman dahulu, di kota Gresik belum ada orkestra. Masyarakat Gresik dahulu masih meyakini, dan tidak menerima selain tradisi maupun kesenian Islam. Akan tetapi, seiring berjalannya waktu masyarakat mulai menerima orkestra karena orkestra tersebut ternyata tidak ber-tolakbelakang. Lagu-lagu yang dibawakan meliputi lagu-lagu religi atau Islami, sehingga masyarakat tertarik serta mengapresiasi. Oleh sebab itu, Smanusa Orkestra yang bernama Nusa Octave Orchestra mengalami perkembangan karak-teristik sampai sekarang. Personil dari pemusik tersebut meliputi siswa - siswi sekolah. Orkestra ini menggambarkan format Big Band Orkestra.

Ketertarikan peneliti untuk mengulas Karakteristik Dan Bentuk Orkestra Nusa Octave SMA NU 1 Gresik dikarenakan memiliki karakteristik primer / pokok yang ke-1 (pertama) menurut peneliti adalah satu-satunya musik orkestra di Gresik, bertempat di sekolah tersebut, dan berdirinya merupakan ide dari kepala sekolah, Drs. H. Moh. Nasihuddin, M.Pd. yang menyukai musik, kemudian mencetuskan ekstrakurikuler orkestra. Selanjutnya, ekstrakurikuler tersebut didukung oleh guru pelatih, Mukmin Efendi, S.Pd. ch.Cht. alumnus Jurusan Sendratasik prodi Pendidikan Sendratasik 2006, Fakultas Bahasa dan Seni, Unesa. Siswa - siswi sangat mengapresiasi sejak awal muncul tahun 2011 sampai saat ini.

Nusa Octave Orchestra memiliki semboyan Young and Talented alias muda dan berbakat. Semboyan tersebut merupakan karakteristik primer / pokok yang ke-2 (kedua). Menurut Mukmin, yang artinya pemuda berbakat ingin selalu beranjak untuk naik terus. Tiada sekat diantara senior dan junior, tiada pilih kasih antara master dan yang mulai dari nol diajari sampai bisa. 
Sehingga, semua tampil bersama bergiliran di setiap kegiatan atau acara. Beranjak untuk naik terus, mengalami perkembangan dari pemain yang awalnya berjumlah 15 orang. Kemudian 30 orang, bertambah 40 orang. Kemudian menjadi 50, bertambah lagi 120 , sampai seterusnya menjadi 200 orang bahkan lebih. Nusa Octave Orchestra pantang menyerah untuk terus berkembang. Terus meningkat sampai Generasi VIII bersiap diri menyambut junior atau regenerasi, Generasi IX. Ekstrakurikuler tersebut dilaksanakan seminggu dua kali, tepatnya pada hari Jumat setelah Jumatan pukul 13.00 - 15.00 WIB, dan hari Sabtu pukul $09.00-12.00$ WIB.

Karakteristik dan bentuk orkestra Nusa Octave termuat dalam Kemendiknas. Nusa Octave berdampak positif dan berkarakter bagi siswa siswi, dengan format Bigband Orkestra yang merupakan gabungan antara alat musik orkestra terdiri dari Strings, Brass \& Wood Wind, Percussion, dan alat musik band rhytm section terdiri dari Gitar, Keyboard, Bass, serta Vokal (Mukmin Efendi, 2015).

Karakteristik Nusa Octave Orchestra banyak terdapat dalam karakteristik sekunder orkestra tersebut antara lain: (1) Open Recruitment Generasi yang artinya setiap tahun dibuka pendaftaran anggota baru / junior atau regenerasi, (2) Pra-Diklat 2 (dua) hari didalam sekolah dan Diklat 3 (tiga) hari 2 (dua) malam diluar sekolah yang artinya dari anggota baru akan diajari untuk rasa saling memiliki satu tim, mendisiplinkan diri, dan selain bermusik diajari managerial waktu, serta berorganisasi, (3) Konser Perdana Junior Nusa Octave Orchestra, (4) Pengenalan lebih dalam tentang Nusa Octave dan Tuning Sebelum Main yang artinya sebelum main dilakukan tuning A untuk menghindari fals, dan agar harmoni, (5) Bentuk pengajaran guru pelatih, jiwa kondaktor, guru pelatih, berbagai pengalaman penampilan orkestra, serta pengaruh budaya Gresik terhadap orkestra tersebut, (6) Latihan Persection yang artinya setiap sebelum latihan bersama dilakukan latihan persection di kelas masing-masing agar persection faham dan kompak, semakin berkembang generasi semakin banyak personil, guru pelatih tidak perlu khawatir karena senior atau ketua section mengajari junior atau anggota sectionnya, (7) Latihan Bersama yang artinya setelah latihan persection akan dikumpulkan di ruang orkestra untuk penggabungan section menjadi Bigband Orkestra, dan mengecek sudah harmoni belum, serta mengundang alumni senior orkestra, (8) Dokumentasi Tampilan Acara yang artinya ada tim panitia kecil atau tim Broadcasting yang gerak cepat setiap tampil acara didokumetasikan di media sosial Web Sekolah www.smanu1-gresik.sch.id, IG resmi (a)nusaoctave, dan dukungannya @ smanusagresik, @smanulgresik_official @smanusabroadcast@mukminefendi@oebed (a) infogresik, beberapa guru lain, siswa-siswi, dan alumni, Youtube dukungannya seperti SMA NU 1 Gresik, Smanusa Broadcast, beberapa guru, siswasiswi, dan alumni, serta sampai termuat di Koran Jawa Pos, Koran Radar Gresik, TV9, TVRI, JTV, SBO TV, dan RAVI TV.

Berdasarkan latar belakang penelitian yang telah diuraikan, penelitian ini menjelaskan Karakteristik Dan Bentuk Orkestra Nusa Octave SMA NU 1 Gresik. Alasan peneliti memilih objek penelitian orkestra tersebut untuk mengetahui bentuk perkembangan adanya musik khususnya musik orkestra di Gresik, ekstrakurikuler yang unik tidak semua sekolah memilikinya dengan difasilitasi alat yang bervariatif dan ruangan musik yang luas, latihan mandiri, siswa - siswi mampu menulis notasi lagu, menciptakan lagu, mengaransemen lagu, maupun rekaman mandiri, menyeimbangkan otak kanan dan kiri, memiliki manajemen panitia harian dan panitia di setiap kegiatan atau acara bertugas mengatur, mempersiapkan dan men-dokumentasikan kegiatan atau acara, serta mengetahui terdapat banyak karakter primer dan sekunder ekstrakurikuler orkestra tersebut, bisa dibuat contoh yang baik untuk dikenal masyarakat, kemudian peneliti mendokumentasikan dalam bentuk tulisan. Selain itu, sebagai ikon musik orkestra satu - satunya di Gresik terus berkembang sampai saat ini, sangat perlu diapresiasi, dilestarikan, dan dipertahankan. Pendokumentasian ini dilakukan agar orkestra tersebut memiliki bukti tertulis. Suatu saat nanti juga bisa digunakan sebagai rekontruksi peneliti atau peneliti lain terhadap orkestra tersebut secara bentuk fisik dalam mempertahakan keberadaannya. Sehingga tetap dikenal, selalu diapresiasi dan dipertahankan oleh masyarakat terutama generasi muda saat ini. 


\section{METODE}

Penelitian mengenai Karakteristik dan bentuk orkestra Nusa Octave SMA NU 1 Gresik menggunakan metode penelitian kualitatif deskriptif. Melalui Penelitian kualitatif deskriptif tersebut merupakan suatu bentuk penelitian yang ditujukan untuk mendeskripsikan fenomena fenomena yang ada, baik fenomena alamiah maupun fenomena buatan manusia (Sukmadinata, 2006 : 72). Fenomena bisa berupa bentuk, aktifitas, karakteristik, perubahan, hubungan, kesamaan, dan perbedaan antara fenomena yang satu dengan fenomena lainnya.

Objek penelitian merupakan sesuatu yang menjadi acuan tindakan dari subjek. Dalam hal tersebut, objek adalah data, kebiasaan, ilmu, sebagai tindakan. Objek penelitian ini adalah Nusa Octave Orchestra, dengan fokus yang dibahas adalah bentuk dan karakteristiknya. Peneliti memilih orkestra tersebut dikarenakan memiliki banyak bentuk dan karakteristik unik yang beda dari orkestra generasi muda lainnya berada didalam lingkup sekolah dan dikenal oleh masyarakat luas.

Subjek penelitian ini peneliti mewawancarai berbagai narasumber yakni: Mukmin Efendi, S.Pd., ch.Cht. selaku guru pelatih orkestra, Ricky Okta selaku ketua orkestra generasi VII, Iqbal Hayes Gavra selaku Ketua orkestra Generasi VIII, dan perwakilan siswa siswi anggota orkestra tersebut.

Teknik pengambilan data dari penelitian ini adalah dengan metode observasi, wawancara, dan dokumentasi. Peneliti menggunakan Observasi Partisipatif, yakni dalam observasi terlibat langsung dengan kegiatan yang sedang diamati, dan data yang diperoleh dari observasi bisa lebih lengkap. Kemudian, pada observasi tersebut, peneliti mengamati apa yang dikerjakan, mendengarkan apa yang diucapkan, dan berpartisipasi dalam aktivitas yang sedang diamati. Peneliti dalam mengumpulkan data dengan cara ikut observasi partisipatif dalam beberapa kegiatan, contonya: kegiatan latihan, kegiatan persiapan penampilan atau hari penampilan, tetapi tidak semuanya. Selain itu, wawancara dilakukan oleh peneliti untuk menggali informasi tentang awal mula terbentuk dan karakteristik orkestra Nusa Octave SMA NU 1 Gresik. Wawancara dilakukan dua tahap yakni wawncara langsung dan tidak langsung. Wawancara langsung dilakukan dengan mendatangi lokasi beberapa kali kepada berbagai narasumber, dan wawancara tidak langsung juga dilakukan beberapa kali melalui pesan singkat (WhatsApp) handphone kepada berbagai narasumber. Selanjutnya, peneliti menggunakan bukti dokumentasi foto, video, dan tulisan sebagai pelengkap penelitian agar terwujud akurat dengan didukung adanya dokumentasi tersebut.

Peneliti menggunakan 2 (dua) teknik pengumpulan data yakni dengan sumber data primer, dan sumber data sekunder. Sumber data primer merupakan sumber data yang penemuannya dilakukan sendiri oleh peneliti ketika melakukan penelitian. Untuk memperoleh data ini peneliti melakukan dengan teknik pengumpulan data (contoh: pencatatan hasil wawancara, hasil observasi lapangan, data dari narasumber, pengambilan foto, dokumentasi, dan melakukan wawancara langsung dengan narasumber yang bersangkutan), berkaitan dengan karakteristik dan bentuk orkestra Nusa Octave SMA NU 1 Gresik. Kemudian, sumber data sekunder diperoleh dari sumber yang tidak langsung. Sumber ini tidak didapat dari narasumber, yakni lewat orang lain atau dokumen. Data sekunder adalah data tambahan untuk melengkapi data primer dimana data tersebut berupa dokumen foto tambahan berkaitan dengan karakteristik dan bentuk orkestra Nusa Octave SMA NU 1 Gresik.

Dalam uji keabsahan data atau proses menarik kesimpulan data, peneliti menggunakan Validitas Data (Triangulasi). Terdapat 2 (dua) validitas penelitian yaitu: validitas internal (triangulasi sumber) dan validitas eksternal (triangulasi pengumpulan data). Validitas internal adalah derajat akurat penelitian dengan hasil yang dicapai, sedangkan validitas eksternal adalah hasil penelitian diterapkan masyarakat menjadi sampel.

Validitas Internal (Triangulasi Sumber), peneliti melakukan dengan cara mengecek data melalui wawancara berbagai narasumber, yakni: Mukmin Efendi, S.Pd., ch.Cht (guru pelatih), Ricky Okta (ketua generasi VII), Iqbal Hayes Gavra (ketua generasi VIII), dan perwakilan siswa - siswi (anggota Nusa Octave). Kemudian mengecek kembali sudah sesuai derajat akurat penelitian dengan hasil yang dicapai atau belum. 
Selanjutnya dimintakan kesepakatan dengan keempat narasumber tersebut untuk menghasilkan keabsahan data / kesimpulan.

Validitas Eksternal (Triangulasi Pengumpulan Data), peneliti melakukan dengan cara mengecek data dengan pengumpulan data. Peneliti bisa melakukan wawancara dengan 4 (narasumber) tersebut atau kepada yang lainnya menjadi sampel, untuk memastikan keabsahan data / valid.

Peneliti menganalisis data dengan melakukan 2 (dua) analisis yakni analisis sebelum di lapangan, dan analisis data selama $\&$ setelah di lapangan. Analisis sebelum di lapangan adalah sebelum di lapangan peneliti melakukan studi pendahuluan untuk mendapatkan fokus masalah yang bersifat sementara, dan berkembang jika peneliti masuk dan selama di lapangan. Peneliti membuat daftar pertanyaan untuk bertanya kepada narasumber. Sebelum di lapangan, merencanakan memilih narasumber valid yang tahu informasi tentang karakteristik dan bentuk orkestra Nusa Octave SMA NU 1 Gresik. Selanjutnya, analisis data selama dan setelah di lapangan adalah setelah melakukan wawancara kepada 4 (empat) narasumber valid yang bersangkutan, serta mengumpulkan buku atau penelitian terdahulu yang relevan mengenai bentuk dan karakteristik Nusa Octave Orchestra SMA NU 1 Gresik. Peneliti mendokumentasikan kegiatan bersama narumber atau objek penelitian sebagai persiapan jika terjadi hal yang tidak diinginkan atau diminta bukti penelitian. Kemudian, mengumpulkan data wawancara, observasi, dan dokumentasi penelitian sebagai jawaban rumusan masalah menjadi kesimpulan. Dalam hal ini, peneliti melakukan 4 (empat) tahap yang diperlukan: pengumpulan hasil data, reduksi data, penyajian data, dan verifikasi.

Pengumpulan Hasil Data merupakan proses mengumpulkan hasil data sebanyak - banyaknya untuk mendapatkan jawaban rumusan masalah dalam penelitian. Proses pengumpulan hasil data tersebut yakni berkaitan judul penelitian, fokus penelitian dengan wawancara, observasi dan dokumentasi tentang karakteristik dan bentuk orkestra Nusa Octave SMA NU 1 Gresik. Reduksi data bisa dibantu dengan alat teknologi / elektronik dengan memberi kode aspek tertentu. Selain itu, reduksi data yakni memfokuskan pada hal - hal yang penting, dan membuang yang tidak perlu. Dalam hal ini, peneliti akan dipandu dengan cara menyaring kembali data yang tidak diperlukan, menyajikan, dan mendapat jawaban rumusan masalah, serta menarik kesimpulan sementara dalam penelitian.

Penyajian data merupakan data yang telah disaring, pemaparan rinci, dan teratur setelah menganalisis dalam bentuk format naratif yang disiapkan. Peneliti akan memahami, memudahkan apa yang terjadi, dan merencanakan tahapan penelitian selanjutnya. Dari reduksi data, kemudian dipaparkan dalam bentuk uraian naratif menceritakan tentang karakteristik dan bentuk orkestra Nusa Octave SMA NU 1 Gresik, dikuatkan dengan tabel, bagan, dan gambar sesuai pembahasan dalam penelitian.

Verifikasi merupakan kesimpulan setelah data ditampilkan sesuai dengan rumusan masalah dan pembahasan penelitian. Verifikasi / kesimpulan adalah inti penelitian. Tujuan verifikasi / kesimpulan yakni memahami makna dari data penelitian, ditemukan pola, tema, hubungan, persamaan, dan lainnya. Dalam hal ini, verifikasi / kesimpulan bisa diteliti kembali selama penelitian sehingga menghasilkan penelitian yang valid / sistemastis.

\section{HASIL DAN PEMBAHASAN}

Awal mula munculnya orkestra Nusa Octave merupakan suatu ide dari kepala sekolah, Drs. H. Moh. Nasihuddin, M.Pd. mencetuskan Musik Orkestra Gresik. Selain itu, untuk mewujudkan SMA NU 1 Gresik sebagai sekolah favorit, di tingkat SMA Indonesia, yang menjadi ikon sekolah percontohan dan mengharumkan kota. Berasal dari beliau yang suka bermusik kemudian membuat Ekstrakurikuler Orkestra untuk mengembangkan bakat minat siswa-siswi di bidang non akademik, seperti tujuan sekolah yakni menghasilkan siswa yang unggul, terampil dalam berbagai bidang akademik maupun non akademik.

Pada orkestra tersebut berawal juga dengan dukungan dari guru pelatih, Mukmi Efendi, S.Pd., ch. Cht. yang merupakan alumnus Jurusan Sendratasik prodi Pendidikan Sendratasik 2006, Fakultas Bahasa dan Seni, Unesa. Pada awal keberadaan orkestra tersebut, telah dianggap bertolakbelakang dengan tradisi Kota Santri atau Kota Wali atau Kota Beriman, maupun kesenian Islami Gresik. 
Konsep ide kepala sekolah dan guru pelatih mengenai orkestra tersebut tidak lepas dari budaya Gresik yang budayanya religius. Sehingga orkestra yang menjadi ikon musik orkestra di Gresik banyak menyajikan (membawakan) lagulagu religi atau Islami dan menyesuaikan situasi kondisi dimana orkestra tersebut tampil agar dapat diterima masyarakat Gresik dan mendapat dukungan dari masyarakat Gresik, serta tidak dianggap bertolak belakang dengan tradisi Kota Santri atau Kota Wali atau Kota Beriman, maupun kesenian Islami Gresik. Dalam kemunculan orkestra bernama Nusa Octave Orchestra yang menjadi inspirasi kepala sekolah dan guru pelatih adalah sebuah orkestra yang akan terus meregenerasi dilestarikan hingga saat ini. Memiliki karakter atau ciri khas tersendiri yang beda dari orkestra pada umumnya seperti memiliki karakteristik primer dan karakteristik sekunder.

Bentuk penyajian orkestra Nusa Octave merupakan sebuah ekstrakurikuler yang berdampak positif berkarakter bagi siswa-siswi, mengasah bakat minat siswa-siswi. Selain itu, bentuk penyajian sebuah pertunjukan orkestra dengan format Bigband Orkestra dengan gabungan antara alat musik orkestra terdiri dari Strings, Brass \& Wood Wind, Percussion, dan alat musik band rhytm section terdiri dari Gitar, Keyboard, Bass, serta Vokal (Mukmin Efendi, 2015).

Tema merupakan penyesuaian dari ide munculnya orkestra Nusa Octave SMA NU 1 Gresik. Menurut Mukmin, tema dalam Nusa Octave ada dalam semboyan yakni Young and Talented alias muda dan berbakat. Berdasarkan semboyan tersebut, artinya pemuda berbakat ingin selalu beranjak untuk naik terus. Tiada sekat diantara senior dan junior, tiada pilih kasih antara master dan yang mulai dari nol diajari sampai bisa. Sehingga, semua tampil bersama bergiliran di setiap kegiatan atau acara. Beranjak untuk naik terus, mengalami perkembangan dari pemain yang awalnya berjumlah 15 orang. Kemudian 30 orang, bertambah 40 orang. Kemudian menjadi 50, bertambah lagi 120 , sampai seterusnya menjadi 200 orang bahkan lebih. Nusa Octave Orchestra pantang menyerah untuk terus berkembang.

Pada penyajian penampilan perform orkestra Nusa Octave menggunakan mode penyajian simbolis yaitu penyajian berasal dari gerak tangan kondaktor guru pelatih dalam memberi aba-aba atau gerak simbolis kepada siswa-siswi pemain musik Nusa Octave. Simbol gerak kondaktor memberikan suatu gambaran lain mengenai penyajian penampilan perform Nusa Octave tersebut. Gerak - gerak unik misalnya gerak tangan kondaktor "UP" maka semua pemain ikut "UP", gerakan tersebut menyimbolkan tentang duduk bersiap diri dimulai penampilan dengan duduk tegap, dan tangan pemain musik bersiap di alatnya masing-masing. Selain cara penyampaian simbol gerak mengetuk tangan, gerakan tersebut menyimbolkan tentang tanda bermain (Hasil wawancara via WhatsApp dengan Gavra selaku Ketua Gen VIII, 10 Mei 2020).

Pemilihan mode penyajian simbolis oleh kondaktor ini menjadikan Nusa Octave sama seperti orkestra pada umumnya yang sigap dan siap menyajikan penampilan yang baik dalam perform orkestra. Kondaktor bisa memasukkan jiwa kondaktornya, dan menguasai atau meletakkan diri sebagai pemimpin dalam orkestra. Dikarenakan beliau sangat menjiwai, maka penyampaian simbolis kondaktor mudah dipahami siswa - siswi pemain musik saat penampilan perform. Sehingga, penampilan menjadi terasa hidup dan bagus di atas panggung atau di depan audien. Meliputi ekspresi, dinamika, tempo sudah bisa tersampaikan oleh beliau kepada pemain musik tersebut.

Pada orkestra Nusa Octave terdapat bentuk manajemen / badan pengurus dengan jabatan selama 1 (satu) tahun dan diadakan pemilihan untuk pergantian badan pengurus di tahun berikutnya. Fungsi dibentuk badan pengurus tersebut sesuai dengan fungsi manajemen menurut Henry Fayol dan GR Terry yang menyebutkan ada 4 (empat) fungsi manajemen yaitu: perencanaan, pengorganisasian, pengarahan, serta pengendalian didalam Nusa Octave.

Fungsi yang pertama adalah perencanaan / planning artinya menyusun rencana strategi untuk mencapai tujuan Nusa Octave. Kemudian, perencanaan merupakan langkah awal yang berpengaruh secara total, dan tidak akan dapat berjalan baik tanpa rencana yang matang. Biasanya diadakan rapat atau musyawarah yang hasilnya mengetahui ketua dan guru pelatih juga dengan persetujuan waka kesiswaan. Selain itu, 
perencanaan memiliki pedoman tujuan yang jelas, efektif, serta fleksibel mengikuti perkembangan.

Fungsi yang kedua adalah pengorganisasian / organizing artinya membuat struktur organisasi atau badan pengurus untuk menentukan siapa pelaksana dan penanggung jawab dalam sesuatu hal di dalam Nusa Octave untuk mencapai tujuan Nusa Octave.

Fungsi yang ketiga adalah pengarahan / commanding artinya memberi arahan kepada anggota Nusa Octave untuk bekerja sama untuk mencapai tujuan Nusa Octave. Pengarahan awalnya dilakukan oleh guru pelatih kemudian dilakukan oleh Ketua badan pengurus atau disebut Presiden Nusa Octave dengan dikomunikasikan dengan baik tidak hanya kepada anggota tetapi juga kepada tim badan pengurus seperti Sekretaris, Bendahara, dan lainnya secara total agar tidak terjadi miss komunikasi.

Fungsi yang keempat adalah pengendalian/ controling artinya mengendalikan anggota Nusa Octave untuk mencapai tujuan Nusa Octave. Pengendalian dilakukan oleh guru pelatih kemudian dilakukan oleh Ketua badan pengurus atau disebut Presiden Nusa Octave dengan dikomunikasikan dengan baik tidak hanya kepada anggota tetapi juga kepada tim badan pengurus seperti Sekretaris, Bendahara, dan lainnya secara total agar tidak terjadi miss komunikasi. Bentuk eksplorasi Nusa Octave adalah mengembangkan adanya musik khususnya musik orkestra di Gresik, ekstrakurikuler yang unik tidak semua sekolah memilikinya. Mengasah bakat dan minat siswasiswi dan mengekplorasi menampilkan untuk mendapatkan rangsangan / respon masyarakat. Eksplorasi dengan difasilitasi alat yang bervariatif, dan ruangan musik yang luas. Kemudian, latihan mandiri yang dilakukan persection atau dipimpin ketua section, dan latihan sendiri tanpa guru pelatih agar menjadi aktif mandiri. Lalu, siswa-siswi dapat mampu menulis notasi lagu, menciptakan lagu, mengaransemen lagu, maupun rekaman mandiri. Kemudian, mengekplorasi meyeimbangkan otak kanan dan kiri. Selain itu, mengeksplorasi dengan memiliki manajemen panitia harian dan panitia di setiap kegiatan atau acara bertugas mengatur, mempersiapkan dan mendokumentasikan kegiatan atau acara.
Ekplorasi dengan Modal utama musik orkestra di Gresik yang mengalami perkembangan yang cukup pesat adalah mempunyai guru pelatih, kemudian pemain mengembangkannya sendiri. Pemain saling berbagi ilmu kepada sesama, dan melakukan latihan mandiri atau sectional atau bersama minimal 1 hari 1 jam (Ricky, ketua generasi VII, 2019). Kemudian, perkembangan yang cukup pesat, telah menambah alat instrumen seperti: Flute, Saxo Sopran, Saxo Alto, Saxo Tenor, dan Mellophone. Saat ini, alat - alat instrumen orkestra tersebut diantaranya: 1 . Trumpet, 2. Trombon, 3. Flute, 4. Mellophone, 5. Saxo Alto, 6. Saxo Alto, 7. Saxo Sopran, 8. Balera, 9. Gitar, 10. Keyboard, 11. Bass, 12. Drum, 13. Violin, 14. Viola, dan 14. Cello (Gavra, ketua generasi VIII, 2020).

Dalam hal ekplorasi tersebut, lagu yang dimainkan pertama kali adalah lagu pop berjudul Jaga Selalu Hatimu dan banyak lagu lainnya dalam rangka mengisi acara, hiburan, serta mengiringi kegiatan atau acara yang dipertunjukan kepada masyarakat Gresik dan luar kota Gresik tingkat Jawa Timur, seperti: mengiringi Wisuda Purna Siswa SMA NU 1 Gresik di Wisma Semen Gresik maupun GOR Petrokimia Gresik, mengiringi Pembukaan Pekan Olahraga Kabupaten Gresik di GOR Petrokimia Gresik, mengiringi Upacara Bendera 17 Agustus 2016 bersama Gubernur dan Kepala Dinas Provinsi Jawa Timur di Grahadi Surabaya, mengiringi Pembukaan O2SN dan FLS2N Tingkat Provinsi Jawa Timur di Alun-alun Batu, mengiringi pelepasan siswa-siswi alumni yang kuliah ke luar negeri di DBL Surabaya, mengiringi Pembukaan Lomba Kreatifitas Siswa SMK Nasional oleh Menteri Pendidikan di Universitas Negeri Malang, menyambut Japanese Culture and Education dan Rajamangala University of Technology Krungthep Thailand pada bulan Oktober 2014 di Aula Idham Khalid SMA NU 1 Gresik, menyambut Acara Presiden di Magelang, mengisi Acara Gus Muwafih di Tuban, mengiringi Acara Gubernur di Jatim Expo Surabaya, mengisi acara di Universitas Brawijaya, mengisi acara di Batusuki, mengiringi Paduan Suara se-Kabubaten Gresik di Gelora Joko Samudro, mengisi acara di Wahana Ekspresi Pusponegoro, menyambut Lomba Olimpiade MIPA \& B. Inggris SMP/MTS se-Kabupaten Gresik PCLP Ma'arif NU Gresik di 
Aula Idham Khalid SMA NU 1 Gresik, mengiringi Arkarna dan Yotari, dll.

Terdapat 5 (lima) manfaat dari eksplorasi tersebut. Diantaranya: 1. Bagi Mahasiswa yakni dapat menjadi acuan mahasiswa khususnya meningkatkan kualitas serta prestasi akreditasi sekolah. 3. Bagi Siswa-siswi yakni siswa - siswi telah difasilitasi dan diwadahi sepenuhnya oleh kepala sekolah, dan guru pelatih agar bisa memanfaatkannya dengan sebaik mungkin. 4. Bagi Kelompok Masyarakat yakni musik orkestra satu - satunya di Gresik dapat mengharumkan kota, menambah wawasan luas meskipun Islami tetap bisa berkembang dalam bermusik orkestra, dan memacu generasi muda penerus bangsa mampu memainkan alat musik orkestra. 5. Bagi Peneliti yakni dapat menambah wawasan dan pengetahuan tentang berbagai karakteristik yang ada dalam Nusa Octave Orchestra tersebut.

Terdapat banyak karakteristik yang bisa dibuat contoh yang baik kepada masyarakat dari adanya orkestra Nusa Octave SMA NU 1 Gresik. Karakteristik Nusa Octave memiliki keunikan yang tidak semua sekolah memilikinya dengan difasilitasi alat yang bervariatif dan ruangan musik yang luas, latihan mandiri, siswa - siswi mampu menulis notasi lagu, menciptakan lagu, mengaransemen lagu, maupun rekaman mandiri, menyeimbangkan otak kanan dan kiri, memiliki manajemen panitia harian dan panitia di setiap kegiatan atau acara bertugas mengatur, mempersiapkan dan mendokumentasikan kegiatan atau acara. Nusa Octave berkarakter dari bulan Februari tahun 2012 / Generasi I sampai sekarang tahun 2020 / Generasi IX.

Karakteristik Primer orkestra Nusa Octave SMA NU 1 Gresik / pokok yang ke-1 (pertama) adalah munculnya Musik Orkestra Gresik memang asing dan menarik untuk diteliti. Beberapa masyarakat tersebut menganggap bertolakbelakang dengan dengan tradisi Kota Santri atau Kota Wali atau Kota Beriman, maupun kesenian Islami. Hal inilah yang menimbulkan beberapa sudut pandang masyarakat tersebut merupakan fenomena unik. Gresik dikenal Kota Santri atau Kota Wali atau Kota Beriman. Smanusa juga dikenal sebagai sekolah akademis berbasis Islam di Kota Santri dengan tidak membatasi adanya musik, musik masuk pembelajaran, dan ekstrakurikuler. Musik mahasiswa program studi Seni Musik untuk turut berkembang, berkarakter, dan semangat seperti Nusa Octave. 2. Bagi Sekolah yakni dapat menjadi contoh yang baik untuk sekolah lain, mengharumkan nama sekolah, dan

Orkestra Gresik satu-satunya bertempat di sekolah tersebut, dan berdirinya merupakan ide dari kepala sekolah, Drs. H. Moh. Nasihuddin, M.Pd. yang menyukai musik, kemudian mencetuskan ekstrakurikuler orkestra. Selanjutnya, ekstrakurikuler tersebut didukung oleh guru pelatih, Mukmin Efendi, S.Pd. ch. Cht. alumnus Jurusan Sendratasik prodi Pendidikan Sendratasik 2006, Fakultas Bahasa dan Seni, Unesa. Siswa siswi sangat mengapresiasi sejak awal muncul tahun 2011 sampai saat ini.

Nusa Octave Orchestra memiliki semboyan Young and Talented alias muda dan berbakat. Semboyan tersebut merupakan karakteristik primer / pokok yang ke-2 (kedua). Menurut Mukmin, yang artinya pemuda berbakat ingin selalu beranjak untuk naik terus. Tiada sekat diantara senior dan junior, tiada pilih kasih antara master dan yang mulai dari nol diajari sampai bisa. Sehingga, semua tampil bersama bergiliran di setiap kegiatan atau acara. Beranjak untuk naik terus, mengalami perkembangan dari pemain yang awalnya berjumlah 15 orang. Kemudian 30 orang, bertambah 40 orang. Kemudian menjadi 50, bertambah lagi 120 , sampai seterusnya menjadi 200 orang bahkan lebih. Nusa Octave Orchestra pantang menyerah untuk terus berkembang. Terus meningkat sampai Generasi VIII bersiap diri menyambut junior atau regenerasi, Generasi IX. Ekstrakurikuler tersebut dilaksanakan seminggu dua kali, tepatnya pada hari Jumat setelah Jumatan pukul 13.00 - 15.00 WIB, dan hari Sabtu pukul $09.00-12.00 \mathrm{WIB}$.

Karakteristik Sekunder orkestra Nusa Octave SMA NU 1 Gresik antara lain: 1. Open Recruitment Generasi yang artinya setiap tahun dibuka pendaftaran anggota baru / junior atau regenerasi, 2. Pra-Diklat 2 (dua) hari didalam sekolah dan Diklat 3 (tiga) hari 2 (dua) malam diluar sekolah yang artinya dari anggota baru akan diajari untuk rasa saling memiliki satu tim, mendisiplinkan diri, dan selain bermusik diajari managerial waktu, serta berorganisasi, 3. Konser Perdana Junior Nusa Octave Orchestra, 4. Pengenalan lebih dalam tentang Nusa Octave dan 
Tuning Sebelum Main yang artinya sebelum main dilakukan tuning A untuk menghindari fals, dan agar harmoni, 5. Bentuk pengajaran guru pelatih, jiwa kondaktor guru pelatih, berbagai pengalaman penampilan orkestra, serta pengaruh budaya Gresik terhadap orkestra tersebut, 6. Latihan Persection yang artinya setiap sebelum latihan bersama dilakukan latihan persection di kelas masing-masing agar persection faham dan kompak, semakin berkembang generasi semakin banyak personil, guru pelatih tidak perlu khawatir karena senior atau ketua section mengajari junior atau anggota sectionnya, 7. Latihan Bersama yang artinya setelah latihan persection akan dikumpulkan di ruang orkestra untuk penggabungan section menjadi Bigband Orkestra, dan mengecek sudah harmoni belum, serta mengundang alumni senior orkestra, 8 . Dokumentasi Tampilan Acara yang artinya ada tim panitia kecil atau tim Broadcasting yang gerak cepat setiap tampil acara didokumetasikan di media sosial Web Sekolah www.smanu1gresik.sch.id, IG resmi @nusaoctave, dan dukungannya@ @smanusagresik, @smanulgresik_official@smanusabroadcast @mukminefendi@oebed@infogresik, beberapa guru lain, siswa-siswi, dan alumni, Youtube dukungannya seperti SMA NU 1 Gresik, Smanusa Broadcast, beberapa guru, siswa-siswi, dan alumni, serta sampai termuat di Koran Jawa Pos, Koran Radar Gresik, TV9, TVRI, JTV, SBO TV, dan RAVI TV.

Open Reqruitment Generasi yang artinya setiap tahun dibuka pendaftaran anggota baru / junior atau regenerasi, merupakan karakteristik sekunder Nusa Octave yang ke-1 (pertama). Tujuan dari diadakan kegiatan tersebut yakni untuk mengembangkan, meningkatkan, mempertahankan, dan melestarikan orkestra tersebut. Setiap tahun ajaran baru, senior orkestra mempersiapkan, memanajemen, menyambut generasi baru dengan membuka pendaftaran anggota baru. Dimulai dari membuat brosur / pamflet tentang pembukaan tersebut yang ditempel di mading - mading sekolah. Pendaftaran anggota baru biasanya ditujukan kepada siswa siswi kelas $\mathrm{X}$ baru yang bingung mau ikut ekstrakurikuler apa, dan tertarik komitmen bergabung dengan ekstrakurikuler orkestra. Dalam hari $\mathrm{H}$ kegiatan tersebut, senior akan menunjukkan bentuk dan karakteristik, serta berbagai pengalaman penampilan didalam orkestra. Kemudian, senior mengarahkan generasi baru tersebut untuk mau berlatih atau main alat instrumen apa yang diinginkan. Setelah itu, guru pelatih, memulai mengenalkan dan memotivasi generasi baru orkestra tersebut. Sebelum resmi menjadi anggota baru, di tes terlebih dahulu, berminat masuk section apa, menguasai atau tidak, kemudian dianjurkan membeli alat musik sendiri agar mudah untuk latihan di rumah, karena fasilitas alat musik orkestra terbatas dan semakin banyak personil di tiap regenerasi.

Melalui Diklat, salahsatu dari karakteristik sekunder Nusa Octave Orchestra yang ke-2 (kedua), dilaksanakan diluar sekolah selama 3 (tiga) hari 2 (dua) malam, merupakan karakteristik terunik dan belum atau jarang komunitas orchestra yang mengadakan kegiatan tersebut. Diklat yang dinamakan TRIFACORA (Training of Nusa Octave Orchestra) diadakan setiap setahun sekali. Tujuannya adalah untuk melatih mental dan ketrampilan / skill anggota baru atau junior agar terbentuk manajemen diri, percaya diri dalam bermusik, mempererat rasa kekeluargaan didalam tim, tidak demam panggung saat tampil diatas panggung atau didepan penonton / audien. Kegiatan tersebut sengaja dilaksanakan diluar sekolah setelah dilaksanakan Pra-Diklat 2 hari didalam sekolah supaya lebih berwawasan luas, lebih fresh di alam dan fokus fikirannya, serta bisa bermusik dengan beradaptasi diluar sekolah. Trifacora dipanitiai oleh kakak kelas atau senior orkestra kepada adik kelas atau junior dibentuk kelompok - kelompok yakni kelompok outbond dan kelompok persection. Dimulai dengan outbond melatih kekompakan antar kelompok, kemudian materi, belajar membaca notasi balok, latihan lagu baru dengan cara latihan persection, dilanjutkan latihan bersama, dan terakhir pentas seni fullteam junior orketsra bersama - sama.

Pelaksanaan kegiatan Diklat regenerasi / TRIFACORA yang merupakan karakteristik sekunder ke-2 (kedua) orkestra tersebut selesai, maka generasi baru secara otomatis ditampilkan/ dipertunjukkan dengan mengundang orangtua masing - masing, untuk datang dalam acara hasil dari proses kegiatan diklat yang dinamakan Konser Perdana Junior Nusa Octave Orchestra di Aula Idham Khalid SMA NU 1 Gresik merupakan 
karakteristik sekunder ke-3 (ketiga) orkestra tersebut. Tujuan dari konser tersebut adalah untuk melatih apa benar sudah bermental kuat, berketrampilan / skill dengan baik, dan melatih manajamen diri, serta melatih agar tidak demam panggung unjuk bakat diatas panggung atau didepan penonton / audien, khususnya menampilkan yang terbaik didepan orangtuanya sebelum tampil di berbagai acara / kegiatan yang dilihat masyarakat luas. Siswa - siswi junior atau generasi baru dituntut untuk dapat memotivasi, membangkitkan semangat diri dan sesama, mempersiapkan dirinya sendiri mulai dari mempersiapkan alat dan berkomitmen antar sesama didalam orkestra, mampu bersikap dan berprilaku baik serta sopan didepan umum maupun didalam orkestra dengan rasa kekeluargaan, juga dapat meningkatkan ketrampilan dalam bermusik orkestra guna meneruskan generasi senior orkestra tersebut.

Karakteristik sekunder ke-4 (keempat) yakni pengenalan lebih dalam tentang Nusa Octave Orchestra dan Tuning Sebelum Main yang artinya sebelum main dilakukan tuning A untuk menghindari fals, dan agar harmoni. Dikenal dahulu, Generasi I - III membaca notasi masih menggunakan Not Angka karena masih awam dengan musik. Kemudian, seiring berjalannya waktu, siswa - siswi mulai diajarkan Not Balok. Selain itu, menampilkan lagu - lagu Pop Indonesia, Pop Barat, Religi, nuansa ensembel tiup, nuansa patrol, dominan banyak request Lagu Religi, tetapi kembali lagi disesuaikan dengan situasi kondisi kegiatan atau acara. Orkestra tersebut memiliki kostum atau baju PDH di setiap generasi dan memiliki ciri khas warna atau aksesoris tersendiri. Lalu, memiliki yel - yel untuk menambah rasa semangat yang dilontarkan guru pelatih atau ketua, sebelum atau sesudah latihan atau penampilan. Kemudian, di setiap pertunjukkan penampilan sebelum main setiap lagu diberi musik pembuka / intro pembuka yang menandakan ciri khas orkestra tersebut.

Karakteristik sekunder ke-5, terdapat dalam bentuk pengajaran guru pelatih, Mukmin Efendi, S.Pd., ch. Cht. telah mengajarkan Nusa Octave Orchestra, dari Generasi I sampai Generasi IX ini, awalnya tidak bisa menjadi bisa, awalnya tidak mengerti musik orkestra jadi mengerti, cara penjarian atau fingering yang benar, cara merawat dan membersihkan alat musik, beliau mengajarkan tangga nada, membaca notasi angka dan notasi balok, berkonsentrasi, melatih kekompakan dan kekeluargaan, tidak membedakan junior dan senior, saling mengajari, memotivasi dan menyemangati satu sama lain, manajemen waktu dan berorganisasi, serta lanjut main lagu.

Lagu yang dimainkan pertama kali adalah lagu pop berjudul Jaga Selalu Hatimu dan banyak lagu lainnya dalam rangka mengisi acara, hiburan, serta mengiringi kegiatan atau acara yang dipertunjukan kepada masyarakat Gresik dan luar kota Gresik tingkat Jawa Timur, seperti: mengiringi Wisuda Purna Siswa SMA NU 1 Gresik di Wisma Semen Gresik maupun GOR Petrokimia Gresik, mengiringi Pembukaan Pekan Olahraga Kabupaten Gresik di GOR Petrokimia Gresik, mengiringi Upacara Bendera 17 Agustus 2016 bersama Gubernur dan Kepala Dinas Provinsi Jawa Timur di Grahadi Surabaya, mengiringi Pembukaan O2SN dan FLS2N Tingkat Provinsi Jawa Timur di Alun-alun Batu, mengiringi pelepasan siswa-siswi alumni yang kuliah ke luar negeri di DBL Surabaya, mengiringi Pembukaan Lomba Kreatifitas Siswa SMK Nasional oleh Menteri Pendidikan di Universitas Negeri Malang, menyambut Japanese Culture and Education dan Rajamangala University of Technology Krungthep Thailand pada bulan Oktober 2014 di Aula Idham Khalid SMA NU 1 Gresik, menyambut Acara Presiden di Magelang, mengisi Acara Gus Muwafih di Tuban, mengiringi Acara Gubernur di Jatim Expo Surabaya, mengisi acara di Universitas Brawijaya, mengisi acara di Batusuki, mengiringi Paduan Suara se-Kabubaten Gresik di Gelora Joko Samudro, mengisi acara di Wahana Ekspresi Pusponegoro, menyambut Lomba Olimpiade MIPA \& B. Inggris SMP/MTS se-Kabupaten Gresik PCLP Ma'arif NU Gresik di Aula Idham Khalid SMA NU 1 Gresik, mengiringi Arkarna dan Yotari, dll.

Karakteristik sekunder ke-6 (keenam) yakni Latihan Persection yang artinya setiap sebelum latihan bersama dilakukan latihan persection di kelas masing-masing. Tujuan latihan persection agar persection faham dan kompak. Semakin berkembang generasi dan semakin banyak 
personil, guru pelatih tidak perlu khawatir karena senior atau ketua section dapat mengajari junior atau anggota sectionnya.

Karakteristik sekunder ke-7 (ketujuh) yakni Latihan Bersama yang artinya setelah latihan persection akan dikumpulkan di ruang orkestra untuk penggabungan section menjadi Bigband Orkestra. Selain itu, mengecek sudah harmoni belum, dan turut mengundang alumni senior orkestra. Modal utama musik orkestra di Gresik mengalami perkembangan yang cukup pesat adalah mempunyai guru pelatih, kemudian pemain mengembangkannya sendiri. Pemain saling berbagi ilmu kepada sesama, dan melakukan latihan mandiri atau sectional atau bersama minimal 1 hari 1 jam (Ricky, ketua generasi VII, 2019).

Karakteristik sekunder orkestra ke-8 (delapan) yakni Dokumentasi Tampilan Acara yang artinya dibuat manajemen, ada tim badan pengurus, tim panitia suatu acara, dan tim Broadcasting yang gerak cepat setiap tampil acara didokumetasikan dalam bentuk gambar seperto foto ataupun video, yang kemudian dimuat di media sosial Web Sekolah www.smanu1gresik.sch.id, IG resmi@nusaoctave, dan dukungannya@ @smanusagresik, @smanulgresik_official, @smanusabroadcast @mukminefendi@@oebed @infogresik, beberapa guru lain, siswa-siswi, dan alumni, Youtube dukungannya seperti SMA NU 1 Gresik, Smanusa Broadcast, beberapa guru, siswa-siswi, dan alumni, serta sampai termuat di Koran Jawa Pos, Koran Radar Gresik, TV9, TVRI, JTV, SBO TV, dan RAVI TV. Dokumentasi tersebut mendapat banyak respon positif dan mendapat banyak dukungan masyarakat luas, bahkan tidak segan untuk sering mendapat tawaran mengisi sebuah acara / kegiatan resmi maupun tidak resmi, serta diundang turut menghibur, memeriahkan sebuah acara / kegiatan tertentu.

\section{PENUTUP}

Berdasarkan hasil penelitian kualitatif, wawancara dan dokumentasi yang telah dilaksanakan oleh peneliti berkaitan Karakteristik Dan Bentuk Orkestra Nusa Octave di SMA NU 1 Gresik dapat diambil beberapa kesimpulan. Kesimpulan tersebut dipaparkan sebagai berikut: 1. Sesuai dengan data peneliti tentang Karakteristik Dan Bentuk Orkestra Nusa Octave
SMA NU 1 Gresik, kesimpulannya adalah orkestra Nusa Octave memiliki beragam karakter atau ciri khas yang sesuai dengan nilai-nilai karakter yang termuat dalam rumusan nilai-nilai karakter menurut Kemendiknas, 2011: 22. Munculnya orkestra Nusa Octave merupakan suatu ide dari kepala sekolah, Drs. H. Moh. Nasihuddin, M.Pd. mencetuskan Musik Orkestra satu-satunya di Gresik, kemudian membuat Ekstrakurikuler Orkestra untuk mengembangkan bakat minat siswa-siswi di bidang non akademik, seperti tujuan sekolah yakni menghasilkan siswa yang unggul, terampil dalam berbagai bidang akademik maupun non akademik. 3. Nusa Octave sebuah orkestra yang akan terus meregenerasi dilestarikan hingga saat ini Gen. IX. Memiliki karakter atau ciri khas tersendiri yang beda dari orkestra pada umumnya seperti memiliki karakteristik primer dan karakteristik sekunder. 4. Faktor pendukung Nusa Octave diantaranya adalah fasilitas sekolah yang mendukung penuh adanya pelaksanaan orkestra sebagai ekstrakurikuler musik yang terus berkembang dan berkarakter, menyediakan ruangan musik orkestra yang luas, membelikan alat instrumen orkestra, serta menjadi musik orkestra satu - satunya di Gresk. Selain itu, siswa - siswi di tiap generasi mendukung dengan latihan rutin 2 (dua) kali seminggu. 5. Faktor yang menjadi hambatan Nusa Octave diantaranya adalah perawatan peralatan instrumen orkestra memerlukan biaya yang tidak sedikit, dan penyampaian materi notasi balok memerlukan proses yang lama dikarenakan beberapa siswa - siswi ada yang belajar musik dari 0 , terkadang jika tidak ada acara / kegiatan, latihan rutin terkadang tidak fullteam kecuali mendekati acara / kegiatan baru fullteam.

Berdasarkan hasil penelitian ditemukan beberapa permasalahan, sehingga peneliti memaparkan beberapa saran. Saran tersebut antara lain sebagai berikut: (1) Peran guru pelatih, ketua generasi dan tim badan pengurus, senior, serta ketua section sangat dominan dalam membentuk karakter anggota Nusa Octave sebagai panutan yang memberi contoh yang baik di lingkungan Nusa Octave tersebut; (2) Strategi untuk mengurangi faktor yang menghambat Nusa Octave adalah untuk antisipasi perawatan peralatan instrumen orkestra memerlukan biaya yang tidak sedikit dengan cara badan pengurus 
seperti Bendahara rutin mengingatkan menabung Kas setiap latihan jadi ketika perlu pengeluaran perawatan tidak bingung dananya. Kemudian, strategi penyampaian materi notasi balok memerlukan proses yang lama dikarenakan beberapa siswa - siswi ada yang belajar musik dari 0 dengan cara rutin latihan mandiri persection dipimpin oleh senior, ketua generasi, atau ketua section, jadi tidak menunggu dilatih oleh guru pelatih baru belajar biar tidak berproses lama. Lalu, latihan rutin yang tidak fullteam mendekati acara / kegiatan baru fullteam sebaiknya ketua mengingatkan untuk bekerjasama dalam tim atau memberi motivasi tentang tujuan Nusa Octave Orchestra; (3) Harus mendapat dukungan dari semua pihak penting terutama sekolah, orangtua, dan masyarakat demi terwujudnya Karakteristik Dan Bentuk Orkestra Nusa Octave SMA NU 1 Gresik dan tetap meregenerasi.

\section{DAFTAR PUSTAKA}

Adyanto, S. P., Muhajir, M., \& Fajriyah, K. (2018). Karakteristik Siswa Anggota Ekstrakulikuler Pencak Silat Ditinjau Dari Nilai Karakter. Jurnal Sinektik, 1(1), 4652.

Ainissyifa, H. (2017). Pendidikan Karakter dalam Perspektif Pendidikan Islam. Jurnal Pendidikan UNIGA, 8(1), 1-26.

Aris Shoimin, Guru Berkarakter untuk Implementasi Pendidikan Karakter, Cet. 1; (Yogyakarta: Gava Media, 2014), h. 29.

Baidhowi, A., \& Yudha Karyawanto, H. (2020). Regenerasi Komunitas Musik Pa'beng Di Desa Bantal Kabupaten Situbondo. Apron Jurnal Pemikiran Seni Pertunjukan, 1(15).

Banoe, P. (2003). Kamus Musik. Yogyakarta: Kanisius.

Deni Damayanti. 2014. Panduan Implementasi Pendidikan Karakter Di Sekolah. Yogyakarta: Araska.

Esterberg, Kristin G. 2002. Qualitative Methods in Social Research New York: Me Graw Hill.

Fathiawati, A. S., \& Sawitri, D. R. (2019). Hubungan Antara Perfeksionisme Dan Music Performance Anxiety Pada Mahasiswa Pemain Orkestra (Doctoral Dissertation, Undip).
Fu'adi. (2009). Mengenal Lebih Dekat Musik Orkestra. Harmonia Jur Sendratasik FBS Unnes ISSN No: 1411-5115.

Hadi, Sutrisno. 2000. Metodologi Penelitian. Yogyakarta: Andi Yogyakarta.

Hutomo, M. P. (2013). Karakteristik Musik Nasyid "Nada Hati” Di Universitas Negeri Yogyakarta. Universitas Negeri Yogyakarta.

Indra Pratama, A. (2016). Peran Humas Dalam Menjalin Kemitran Sekolah di SMA NU 1 Gresik. Inspirasi Manajemen Pendidikan, 4(1).

Inriyani, Y., Wahjoedi, W., \& Sudarmiatin, S. (2017, June). Peran Kegiatan Ekstrakurikuler untuk Meningkatkan Prestasi Belajar IPS. In Prosiding Seminar Nasional Mahasiswa Kerjasama Direktorat Jenderal Guru dan Tenaga Kependidikan Kemendikbud 2016.

Koellhoffer, Tara Tomczyk. (2009). Character Education Being Fair and Honest. New York: Infobase Publishing

Moh. U dan Lilis. (1993). Upaya Optimalisasi Kegiatan Belajar Mengajar. PT. Remaja Rosdakarya: Bandung.

Moleong, J. Lexy, 2001, Metodologi Penelitian Kualitatif. Bandung: PT Remaja Rosdakarya.

Mulyasa.H.E. 2011. Manajemen Pendidikan Karakter. Jakarta: PT Bumi Aksara.

Nehe, A. I. (2019). Keberadaan Orkes Keroncong KKAJ di Jombang. Virtuoso (Jurnal Pengkajian dan Penciptaan Musik), 2(2), 71-77.

Faridatin, N. (2016). Kota Gresik Sebagai Kota Santri "Implikasi Sebagai City Branding". THAQAFIYYAT: Jurnal Bahasa, Peradaban Dan Informasi Islam, 17(1), 106-121.

Pantu, A., \& Luneto, B. (2014). Pendidikan Karakter dan Bahasa. Al-Ulum, 14(1), 153170.

Peraturan Menteri Pendidikan Republik Indonesia Nomor 62 Tahun 2014 tentang Kegiatan Ekstrakurikuler Pada Pendidikan Dasar dan Pendidikan Menengah.

Rena Lailatul A, N. U. R. (2017). Pembelajaran Biola Pada Ekstrakurikuler Orkestra Di 
Smp Negeri 6 Surabaya. Jurnal Pendidikan Sendratasik, 5(1).

Rohmatillah, R. (2013). Implementasi Bahasa Mandarin sebagai Bahasa Asing di SMA Nahdlatul Ulama 1 Gresik. Jurnal Kebijakan dan Pengembangan Pendidikan, 1(2).

Setiawati, N. A. (2017, October). Pendidikan Karakter Sebagai Pilar Pembentukan Karakter Bangsa. In Prosiding Seminar Nasional Tahunan Fakultas Ilmu Sosial Universitas Negeri Medan (Vol. 1, No. 1, pp. 348-352).
SMA Nahdlatul Ulama 1 Gresik. (2012). Kurikulum SMA Nahdlatul Ulama 1 Gresik 2012/2013 (Perbaikan). Gresik: Unipress SMA NU 1.

Sugiyono, 2012. Buku Metode Penelitian Kuantitatif Kualitatif dan R\&D. Alfabeta. Bandung.

Sukohardi, AL, 1978. Teori Musik Umum. Yogyakarta: Pusat Musik Liturgi.

Suryosubroto, B. 1997. Proses Belajar Mengajar Di Sekolah. Jakarta: Rineka Cipta. 